\title{
From a Supranational Air Authority to the Founding of the European Civil Aviation Conference (ECAC)
}

\author{
Christian HENRICH-FRANKE
}

The integration of pan-European transport systems was one of the first matters to be discussed in the early years of European integration after the end of World War II. Specifically in the field of civil aviation a variety of very ambitious concepts was put on the agenda from 1951 onwards. In November 1955 the discussion on how to integrate the civil aviation sector reached its first climax when the representatives of 19 European aviation authorities adopted a resolution formally constituting the European Civil Aviation Conference (ECAC).

This paper will portray the decision-making process which lead to the founding of the ECAC - here simply called 'air integration'. In order to be able to give a more detailed explanation special reference will be made to the different actors involved on the national as well as on the international level. The questions to be answered in this context are: What were the motivations of the different actors? In how far were the discussion and its outcome linked to a general political and economic European integration or to more specific projects of European transport integration? Which role did different international organisations play? How did the economic needs of national airline companies influence 'air integration'?

Whenever this paper speaks of Europe it relates only to Western Europe and excludes those countries belonging to the so-called Eastern European bloc. Special attention is paid to the national attitudes of Germany, Great Britain and the Netherlands as these were traceable in archival material. Although this small selection is far from being representative for the whole of Europe - especially when taking into account the absence of France - it probably offers the broadest possible variety.

The term integration is used rather vaguely and includes economic as well as political aspects: The economic aspects include all attempts to raise the efficiency of intra-European airline operation be it by means of liberalisation or by means of coordinated regulation. Political integration means any kind of formal institutionalisation of decision-making processes on the European level.

\section{General Conditions for ,Air Integration' in 1950}

\section{Characteristics of European Civil Aviation}

In 1950 the civil aviation sector was highly regulated by national governments. Nearly all airline companies belonged more or less directly to the state. This was partially due to defence reasons but also to the high prestige value of national 
airline companies. ${ }^{1}$ Therefore the European market was strictly divided among the different national airline companies. Moreover the majority of domestic markets were very small and the distances to be covered very short, which kept the airline companies from making use of the economies of scale and scope. Although the average air fare in Europe was 50\% higher in comparison to that in the United States the operation of domestic and intra-European air routes depended on subsidies by the governments. ${ }^{2}$ Only the intercontinental air routes could be operated profitably. ${ }^{3}$ Apart from the above mentioned economic burdens, intra-European air transport was in a disadvantaged competitive situation compared to all other means of transport. By the time civil aviation began to operate on a large scale, the network of railways and roads was already very dense. In 1950 air transport therefore was still negligible concerning its capacity; in 1948, even on the busy London-Paris route, the share of air passenger traffic represented only $10 \%$ of the total amount of passenger-traffic by boat, road or train. ${ }^{4}$

\section{Existing forms of international cooperation}

From a juridical point of view the most important international organisation was the universal International Civil Aviation Organisation (ICAO), established in 1944. Its general aim was to foster international air transport in all aspects and to develop the principles and techniques of air navigation. Although later the ICAO made much progress in the fields of technical, navigational and safety standards it had failed to promote joint operation of air routes on a worldwide or even a regional basis. In the context of European civil aviation it is important to note that various studies of the ICAO on the establishment of an intra-European multilateral agreement on operating rights were laid aside as the European member countries were only willing to accept certain general rules and principles.

The second major global organisation was the non-governmental International Air Transport Association (IATA). Established in April 1945 by the majority of the world's international airline companies its organisational roots dated back to 1919 . Often underestimated the IATA had a tremendous influence on the fixing of international tariffs. Since the IATA required unanimity, tariffs were fixed at such a high level that even the most inefficient airline was able to consent. The majority of

1. H.A. WASSENBERGH, Post-war International Civil Aviation Policy and the Law of the Air, Nijhoff, Den Haag, 1957.

2. H. REUM, Koordinierung der innereuropäischen Lufttransporte. Unpublished report to the German ministry of Transport in August 1951, Bundesarchiv, Koblenz (BArch), Bestand Verkehrsministerium, B146/425.

3. P. BROOKS, The development of Air Transport, in: Journal of Transport Economics and Policy, 2(1967), pp.164-183; P. LYTH, Sky Wars: Conflicting Approaches to Air Transport Regulation in Europe and the United States 1920 to 1990, in: L. ANDERSSON-SKOG, O. KRANTZ, Institutions in the transport and communications industries, Science History Publ., Canton, 1999, pp.93-112.

4. Council of Europe, Consultative Assembly, Third Ordinary Session, Report on the Co-ordination of intra-European Air Transport, Doc.59, 26.11.1951. 
national governments appreciated the IATA's efforts because they expected that international price competition would result in increased subsidies. Peter Lyth therefore characterizes the IATA as "probably one of the most successful price cartels of the twentieth century". 5

The most advanced project of cooperation at that time was the regional association of the national airline companies of Denmark, Norway and Sweden within the Scandinavian Airline System (SAS) which was founded in August 1946. ${ }^{6}$ From October 1950 onwards the SAS covered all the intra-European air routes of the participating companies. SAS got its own air crews for operation but chartered the aircrafts from the three national airline companies. Within Europe the national resources were pooled by a joint representation in foreign countries, a joint repair service and a joint operating system. On account of the SAS the Scandinavian airline companies were able to operate more efficiently and to increase their importance on the international markets beyond a point they could have attained individually.

By 1950 the major part of intra-European cooperation was still carried out on the basis of bilateral agreements between national governments. These concerned mainly three aspects: (a) The establishment of individual routes; (b) The transfer of traffic rights and (c) the capacity and frequency of services. Among the 19 countries, which became a member of the ECAC in 1955, exactly 171 separate bilateral agreements were concluded. ${ }^{7}$ This dense network of bilateralism made air route distribution a highly protected market. Governments bargained carefully to restrict the number of foreign competitors serving national airports and the frequency of flights to a degree that the national flag carriers were favoured. ${ }^{8}$ Due to the bilateral negotiations, the development of a transnational European air route network became suppressed. Each company had its own intra-European network of feeder links being centred at the airports at the end of their intercontinental air routes. This resulted in twice as many miles of air routes in ECAC-Europe as there were in the US, despite the area of Europe being considerably less than half of that of the US. Apart from bilateralism on the governmental level, a similar network of pooling agreements had been established between the airline companies themselves. These agreements dealt e.g. with restricting the capacities to be operated by each partner in order to avoid excess on parallel served routes, or with the sharing of operational staff. ${ }^{9}$

To sum up, in 1950 there did not exist any international organisation nor a multilateral agreement defining an overriding European aviation policy. Although a

5. P. LYTH, Institutional Change and European Air Transport, 1910-1985, in: L. MAGNUSSON, J. OTTOSON, Evolutionary Economics and Path Dependence, Elgar, Cheltenham, 1997, p.177.

6. J. OTTOSON, The Making of a Scandinavian Airline Company, in: L. ANDERSSON-SKOG, O. KRANTZ, op.cit., pp.267-279.

7. S. WHEATCROFT, The Economics of European Air Transport, Manchester University Press, Manchester, 1956, p.233.

8. R. THORNTON, Governments and Airlines, in: International Organization, 3(1971), pp.541-553.

9. S. WHEATCROFT, op.cit., p.258. 
multitude of organisations and agreements dealt with a manifold package of measures, each of them only regulated partial aspects of intra-European air transport. What they all had in common was a rather restrictive tone reducing the competition between airline companies to a minimum degree.

\section{Proposals for European 'Air Integration'}

In 1950 and 1951 several proposals were introduced within the Council of Europe $(\mathrm{CoE})$ and the Organisation for European Economic Cooperation (OEEC) with the aim of integrating the aviation sector.

\section{Council of Europe}

(A) The Bonnefous-Plan: On May $11^{\text {th }}$ 1951, Edouard Bonnefous, president of the Committee of Foreign affairs of the French National Assembly, submitted to the Consultative Assembly ${ }^{10}$ a detailed report on the creation of a supranational European transport authority with the responsibility to coordinate different modes of transport: Civil aviation, railroad, road traffic plus costal and inland navigation. ${ }^{11}$ In the special field of civil aviation this report, better known as the Bonnefous-Plan, proposed to convene a conference of government and airline company experts which should decide on the best way to establish a single European company to operate air services in Europe. This report was based on the assumptions that the intra-European air route network was clearly separated from the intercontinental one and that the operation of intra-European air traffic required the solution of specific political, economic and technical problems.

Bonnefous, following the vision of a future political unification of Europe, regarded European infrastructure networks as prerequisites for a politically unified Europe. ${ }^{12}$ Even more he favoured the approach of functional integration which meant integration of the European economy sector by sector. The Bonnefous-Plan can be considered as one among other similar French plans to integrate the coal and steel sector, ptt, pharmaceutics and agriculture. ${ }^{13}$ However, according to Bonnefous,

10. From now on the short form Assembly will stand for the Consultative Assembly of the Council of Europe.

11. Council of Europe, Consultative Assembly, Third Ordinary Session, Report on the Co-ordination of European Communications and the Establishment of a European Transport Authority, Doc.11, 05.05.1951.

12. E. BONNEFOUS, L'Organisation européenne des transports, in: Notre Europe, 1951, pp.45-46.

13. Following this line of policy in 1955 he even took the initiative for the integration of European ptt-services which in the long term resulted in the founding of the „Conférence Européenne des Administrations des Postes et des Télécommunications“ (CEPT) in 1959. See C. FRANKE, Das Post- und Fernmeldewesen im europäischen Integrationsprozess der 1950/60er Jahre, in: European Journal of Integration History, 2(2004), pp.95-117. 
transport was one of those sectors where "it is easiest to advance rapidly and obtain tangible results". ${ }^{14}$

(B) The Van de Kieft-Plan: In November 1951, on behalf of the Committee on Economic Questions the Dutch socialist Johan Van de Kieft presented to the Assembly a plan which dealt with 'air integration' from a purely economic point of view, leaving visions of a future political unification of Europe completely out of consideration. ${ }^{15}$ As the Van de Kieft-Plan furthermore took into account the willingness of European governments to pay the price of subsidies in order to protect their national airlines it assessed any kind of supranational organisation as a matter of a distant future. On the other hand it stressed that appropriate measures to increase the sector's efficiency were a matter of public responsibility. The report pointed at the success of the SAS and proposed the setting up of a single European association to operate air route services between the member states of the CoE as a long-term objective. This should not get a separate legal identity but have responsibility for allocating intra-European routes, timetables, operational frequencies, capital investments and the profits between the associated companies. To reach this goal the Van de Kieft-Plan recommended the convening of a conference of governmental experts and airline company representatives to consider the establishment of such an association. As a short-term matter the conference should report on other measures to assist the economically efficient operation of European air transport. ${ }^{16}$

(C) The Sforza-Plan: On May $4^{\text {th }} 1951$ the Italian minister for European affairs, Count Carlo Sforza, presented to the CoE's Committee of ministers an outline considering the integration of European airline services, the Sforza-Plan. This plan obtained much more political attention than both other plans discussed within the Assembly because (a) it was presented within the Committee of ministers and (b) it was supported by the CoE's secretary-general who judged the general principles of the plan as "a decisive step towards a practical application of the concept of European nationality". ${ }^{17}$

In detail the Sforza-Plan proposed the founding of a joint European airspace including overseas territories and of a syndicate at the level of airline companies to conduct all intra-European operations. Its responsibility should include the grouping of operational methods by the unification and the rationalisation of the air route network. Concerning the measures to be taken to reach this goal, the plan was rather vague, only stating that all assets and equipment of European operators

14. Council of Europe, Consultative Assembly, Second Ordinary Session, Motion recommending the creation of a European Transport Organisation, Doc.63, 16.08.1950.

15. Council of Europe, Consultative Assembly, Third Ordinary Session, Report on the Co-ordination of intra-European Air Transport, Doc.59, 26.11.1951.

16. E. VERPLOEG, The road towards a European common air market: Civil aviation and European integration, Kemink, Utrecht, 1963.

17. Considérations sur le projet italien d'unification aérienne européenne - Déposé au Secrétariat Général du Conseil de l'Europe, CM/Adj. (51)19, Archives of the Council of Europe, Strasbourg (ACE). 
should eventually become completely pooled. The European airspace was to be managed by a supranational high authority to which the syndicate should become subordinated. It should be instructed in all matters of airline operation to negotiate bilateral agreements with non-European countries. Furthermore the high authority should be placed within the existing framework of international organisations with direct responsibility towards the OEEC in economic matters and towards the $\mathrm{CoE}$ in political matters. ${ }^{18}$

The vision behind the Sforza-Plan seemed to be purely political. Being rather specific in outlining the political implications of the proposed measures the plan did not really consider juridical, economic or technical consequences. Neither had Italian experts on civil aviation been consulted while it was being worked out. ${ }^{19}$ For Sforza 'air integration' represented one further element on the way towards a European political community. To him, integration in the civil aviation sector symbolized more than any other projects the tearing down of the political borders dividing the peoples of Europe.

\section{OEEC}

In July 1951 the Scandinavian countries of Denmark, Norway and Sweden introduced to the OEEC a memorandum recommending to free airline companies from all existing bilateral restrictions on the scale and frequency of air services within Europe. To guarantee the rules for free competition a permanent body under the aegis of the OEEC - not inevitably governmental - should be set up. Airline companies should be enabled to establish air routes wherever they found there was an uncovered demand for air transportation. ${ }^{20}$ In the long run the permanent body should replace the whole system of bilateral agreements between the European governments. ${ }^{21}$ The Scandinavians had chosen the OEEC for their proposal hoping that it would discuss the economic contents of the proposal without taking into consideration a political unification of Europe.

The Scandinavian proposal was driven by purely national economic considerations. It aimed at increasing the efficiency of airspace usage in Europe by lowering the degree of regulation in the civil aviation sector. Such a proposal was only logical as the Scandinavian countries could nothing but gain from liberalisation: (a) Their own domestic markets were only small and rather unattractive for other European airline companies; (b) They found themselves

18. Italian Plan for European Air Unification, CM/Adj. (51)19 Appendix, ACE.

19. Correspondence between the Italian and British ministries of Transport, National Archives London (NA), Foreign Office's Records (FO) 371/99728.

20. Joint Memorandum by the Danish, Norwegian and Swedish delegations to the OEEC on Liberalisation of Air Transport between Member States, Archives of the OEEC, Florence (AOEEC), Doc.C(51) 236.

21. Summary of the discussion by the group of experts on the Scandinavian memorandum, Annex II, AOEEC, Doc.C(52) 48. 
being in a strong competitive situation after the merger of their airlines within the SAS.

\section{Summary of proposals}

The Bonnefous and the Sforza-Plans were both driven primarily by political visions of a future united Europe. A transnational European air route network being regarded as a striking symbol for a unified Europe - could for both best be build up by establishing a supranational institution to regulate European airspace. The Van de Kieft-Plan in contrast neither followed a guiding political vision nor was it aimed directly at the creation of a transnational European air route network. Starting from a simple analysis of the economic situation of civil aviation it proposed short-term measures to increase the sector's efficiency without neither upsetting the whole system of bilateral agreements nor explaining in detail if this should be reached by intergovernmental regulation or by liberalisation. In other words, it postponed all controversial issues to an undefined future. The Scandinavian proposal in contrast was formulated very clearly: It stated that a European air route network meeting the demand for air transportation was only reachable by complete liberalisation of the civil aviation market. Without any political vision attached, a specialized European body was regarded as being of secondary importance and such a body should have to concentrate on guaranteeing free competition.

\section{Attitudes towards 'Air Integration'}

\section{Germany}

The independent German civil aviation activities ended with the treaty of Potsdam in August 1945. From then on the allied powers' airline companies took over the operation of the German air route network and by that divided the German aviation market into many pieces. Ironically in the period before World War II the German Lufthansa had been the only airline with a dense network of European and national air routes. ${ }^{22}$ Germany did not get back its sovereign right to operate civil airline services before $1955 .^{23}$

Under these circumstances the German attitude towards 'air integration' became inseparably connected with the question of regaining civil aviation sovereignty. Concerning the proposals under discussion the inner-German debate thus focused on the Sforza-Plan, as neither the contents of the Van de Kieft-Plan nor of the Scandinavian OEEC-memorandum were of direct concern for Germany.

22. H. BONGERS, Deutschlands Anteil am Weltluftverkehr, Meiner, Leipzig, 1938.

23. H.-U. DIENEL, Lufthansa: Two German Airlines, in: H.-U. DIENEL, P. LYTH, Flying the Flag. European Commercial Air Transport since 1945, MacMillan, London, 1998, pp.87-125. 
The Bonnefous-Plan did not get any support either, because the ministry of transport insisted upon a separation of air and inland transport.

For Germany, the gradual transfer of national sovereignty as intended in the Sforza-Plan was a delicate matter. The German government was simply unable to negotiate the transfer of competence, which it did not yet exercise. More than in other countries the ministries concerned were therefore divided: Especially the ministry of Transport, most eager to rebuild the Lufthansa, was ready to accept a transfer of competence only to a minimum degree. Instead it supported airline cooperation in compliance with the pattern of the SAS. ${ }^{24}$ In contrast the minister of Justice expected a supranational European authority to be the fastest way to get rid of the restrictions on German civil aviation. He therefore recommended an active support of the Sforza-Plan but underlined the need for further discussion of its juridical impacts. The negotiations on the Schuman-Plan had already shown that the most effective solution to dispose of occupational restrictions was by means of European arrangements. ${ }^{25}$ In the end, Germany adopted a compromise position of wait-and-see policy, which was proposed by the Foreign ministry's expert on Western European matters, Carl Friedrich Ophüls: The positive attitude towards European integration in general was signalized by expressing the willingness to further discuss the contents of the Sforza-Plan. At the same time international negotiations were only passively observed as German delegates were unable to take part on an equal footing, even if they had exercised full membership status within the $\mathrm{CoE} .{ }^{26}$ Concerning the Scandinavian OEEC proposal the German position was to exercise restrained but to clearly signalize support for its contents. It was expected that by lowering the degree of regulation the burdens for future German civil aviation would be eased. ${ }^{27}$

Apart from these reserved tactics within the CoE and the OEEC the question of 'air integration' offered an opportunity to offensively approach the AHC concerning the re-establishment of an independent German airline company. ${ }^{28}$

\section{Great Britain}

At the beginning of the 1950s, the British airlines were entirely state-owned enterprises. Both companies, the British Overseas Airway Corporation (BOAC) and the British European Airways (BEA), operated profitlessly and were thus

24. Report of the German minister of Transport, Seebohm, to the Foreign ministry, BArch, Bestand Bundesministerium für den Marshall-Plan, B146/425.

25. Report of the German minister of Justice, Dehler, to the Foreign office, Bestand des Auswärtigen Amts, Politisches Archiv Berlin (PA), B 10-794.

26. Record of the German Foreign ministry's coordinator Ophüls concerning the creation of a European Air Union, PA, B 10-794.

27. Telex from the German Foreign ministry to the permanent delegation at the OEEC in Paris, BArch, Bestand Bundesministerium für den Marshall-Plan, Bundesarchiv, B146/425.

28. Correspondence of the German Foreign ministry with the Allied High Commission (AHC), PA, B 10-794. 
dependent on government subsidies. Especially the BEA suffered from a low utilization with an overall load factor of only $58 \%$ in 1951 . The separation of British airlines into two companies resulted for both of them in comparatively high cost structures and thus in a weak position on the European civil aviation market. On the routes to the Netherlands and Scandinavia for example, BEA carried only $20 \%$ of the overall traffic. ${ }^{29}$ For economic reasons the British government therefore in principle supported common European activities to promote civil aviation's efficiency. ${ }^{30}$ For political reasons, on the other hand, the government reacted with restraint: (a) It did not want to accept a European institution exercising power over a state-owned British enterprise; (b) It feared that attempts by European states to regionalize air transport would encourage other parts of the world to do the same with ensuing losses for European long-distance operators like BOAC; (c) It generally disliked the founding of further European organisations - especially supranational ones.

The correspondence on the different proposals was handled exclusively by the Foreign Office (FO), for whom the question of 'air integration' was one of highest political importance:

"The difficulty in this case is that we are faced for the first time with an aspect of European integration which is detrimental to our own interest. Although the Schuman-Plan, the E.D.C., the Pflimlin-Plan and the European Political Authority may cause us difficulties in the future, they are not inherently dangerous from the United Kingdom standpoint. [...] But the mere attempt to organise European airlines on a purely regional basis may well have unfortunate repercussion in other parts of the world which might gravely affect the operation of our own airline routes". ${ }^{31}$

With regard to the proposals under discussion the FO preferred the Van de Kieft-Plan, but emphasized that the proposed conference of experts should not solely be concerned with establishing an association of airline companies. It should rather concentrate on an improvement of the current economic situation. In principle, the FO did not want any major changes in the existing international political order within the aviation sector and gave therefore preference to a regional air transport commission within the juridical framework of the ICAO - a possibility offered by article 55 of the ICAO convention. It was convinced that the system of bilateral agreements in combination with the efforts of the IATA achieved considerable success, which could not be overlooked and should not be jeopardised. ${ }^{32}$

The Scandinavian proposal seemed completely unacceptable: (a) Politically, the FO did not want to foster the proliferation of agencies set up under the aegis of the OEEC; (b) Economically, a complete liberalisation of air operations was regarded

29. P. LYTH, Aircraft procurement and operating cost at British European Airways, in: Accounting, Business and Financial History, 1(1993), pp.1-20.

30. Draft brief for Foreign ministers advisor at the Council of Europe, NA, FO 371/99728.

31. Report of the Foreign Office's delegate de Zulueta on the British proceedings in the context of the French invitation, NA, FO 371/99729.

32. Statement of FO towards the ministry of Civil aviation, NA, FO 371/99728. 
as too radical for the BEA. The 'Sforza-Plan' was disregarded for being a result of the "growing federalist feeling in Europe" which produced a series of hopelessly ambitious proposals to integrate the European economy sector by sector. For the same reason the Bonnefous-Plan had not even been held worthy of being taken into consideration. ${ }^{33}$

\section{The Netherlands}

At the end of World War II, apart from the British and the Swedish airline companies, the Dutch KLM was the last airline company still operating intra-European services, even if only on a very low level. Using aircrafts which had escaped the German invasion because they had at the time been located abroad, the KLM served the air route Bristol-Lisboa on the basis of a commission by the British government. ${ }^{34}$ Furthermore, KLM had permanently run air routes within Asia during the war. The ability to immediately restart operations and the absence of its pre-war competitor, the German Lufthansa, worked in favour of KLM. It soon recovered and operated cost-effectively, even with limited profit. In 1951, the overall load factor achieved a comparatively high level of $68 \%$. Just like Dutch transport policy in general, the aviation policy, too, had traditionally been very liberal. With a domestic market being too small to run an airline company cost-effectively, KLM was dependent on the access to international markets. ${ }^{35}$

After an intensive exchange of views between the Foreign ministry and the ministry of Transport, the Dutch government assessed the liberalisation of European civil aviation as an objective of overriding importance. Not one single company or association should operate intra-European air routes but several companies should compete. KLM was expected to gain from competition but to lose from any kind of market regulation carried out by a European organisation. Therefore, the Scandinavian OEEC proposal was supported primarily. This was also in line with the general Dutch policy of pleading for a closer connection of European economies within the framework of the OEEC. ${ }^{36}$ Concerning the plans within the CoE, the Dutch preferred the Van de Kieft-Plan ${ }^{37}$ as this (a) offered in its economic considerations the opportunity for liberalisation and (b) did not aspire to the creation of a European body regulating the aviation market, at least in the short term. Both the Sforza and the Bonnefous-Plan seemed unacceptable, because they

33. Confidential memorandum of the Foreign Office, NA, FO 371/99729.

34. M. DIERIKX, KLM: An Airline Outgrowing its Flag, in: H.-L. DIENEL, P. LYTH, Flying the Flag ..., op.cit., pp.126-158.

35. M. DIERIKX, En spel zonder kaarten: KLM-landingsrechten als nationaal belang, 1945-1957, in: D.A. HELLEMA, C. WIEBES, B. ZEEMAN, Jaarboek Buitenlandse Zaken: Deerde Jaarboek voor de geschiedenes van de Nederlandse buitenlandse politiek, Sdu uitgevers, Den Haag, 1997, pp.11-25.

36. A. MANNING, Die Niederlande und Europa von 1945 bis zum Beginn der fünfziger Jahre, in: Vierteljahrshefte für Zeitgeschichte, 1(1981), pp.1-20.

37. Remarkably Van de Kieft was appointed minister of Finance in the Netherlands in 1952. 
wanted to unify and rationalize the European air route network through regulation carried out by a common body. ${ }^{38}$ Neither did the Dutch appreciate further political integration, as aimed at by both plans.

\section{Summary of attitudes}

While in Germany and the Netherlands the official government attitude was formulated with reference to the needs of the civil aviation sector, the British attitude was influenced by the general integration policy. This was due to the involvement of different ministries on the national level: In Britain the FO was the main force while in Germany and the Netherlands several ministries took part on equal rights. The political vision of 'air integration' being a symbol of or a step towards a future politically united Europe did not get any support. Instead it arose opposition as in the case of Britain. Even more in Britain the intra-European air route network was regarded as an integral element of a world-wide network. Therefore negative consequences on British world-wide airline services were feared. Remarkably in all three countries the support for 'air integration' to a large part depended on the expectation of how much the national airline company could gain.

\section{International Discussion on ,Air Integration'}

\section{OEEC}

When a group of experts set up by the OEEC held its session in November 1951, the Scandinavian proposal gave rise to a polarized discussion: On the one hand, especially the French and Belgian delegates criticized that complete liberalisation would result in "wasteful competition" and weaken the efficiency of civil aviation even more. According to them a fully developed and efficient European air route network could not come into being without regulation by the authorities. For economic and political reasons they both preferred the proposals to be put forward within the CoE. On the other hand the Scandinavians, being supported by the Netherlands delegate, declared greater freedom of operations as a requirement for progress in the civil aviation sector. ${ }^{39}$ Also the Swiss and the Austrians backed this position, neither of whom was represented in the CoE.

The British delegates acted accordingly to a tactical proceeding passed to them by the FO: This consisted in focussing criticism on the political aspect that the

38. Papers on the internal discussion between different ministries, Nationaal Archief Den Haag, Ministerie van Buitenlandse Zaken (MBA), 2.05.59.02.1501.

39. Summary of the Discussion by the Group of Experts on the Scandinavian Memorandum, Annex III of the Report by the Joint Trade and Payments Committee on the Liberalisation of Invisible Transactions, Doc.C(52)48, AO. 
OEEC was not the proper forum and in formulating only modest criticism of the economic contents. The FO calculated with the Scandinavians and the Dutch being able to consent to the concept of a regional committee under the ICAO, if the full examination of the proposal's economic contents was promised. ${ }^{40}$ At informal meetings within UniScan this point had already been under consideration. To get German support, the AHC held out the prospect that Germany could take the first step towards membership within the ICAO by accepting the British concept. ${ }^{41}$

Taking these divergent positions into consideration the group of experts found itself in a deadlock situation. Since no compromise position seemed reachable, the matter was transferred to the OEEC council for decision. At that point it was already certain that the Scandinavian proposal would fail because a gentlemen's agreement required unanimity for action at higher level. Without being able to reach such unanimity the Council in April 1952 finally decided to defer further study of the matter. It formally took note of the proposal, which meant it was politely shelved.

The Scandinavian delegates reacted by reserving the right to raise the question again if so desired. By doing so, they secured themselves an influential position for the ongoing discussion on 'air integration' within the CoE. Already on the same day, the Swedish delegate made use of that position and warned the UK delegation that although his government firmly opposed discussing this subject in Strasbourg, it was prepared to raise the OEEC proposal once again, in case the ICAO did not consider liberalisation. ${ }^{42}$ In addition, the Swedish delegate informed the Dutch Foreign ministry that a politically neutral forum, which would seriously consider liberalisation of European civil aviation, was a prerequisite for further discussion. ${ }^{43}$

\section{Air Research Bureau}

In October 1952, six European airline companies (BEA, KLM, SAS, Air France, Swissair and the Belgian Sabena) formed the Air Research Bureau (ARB) to study possibilities of various forms of cooperation. After the ongoing debate within the $\mathrm{CoE}$ at that time was circling around political and diplomatic questions and losing touch with the economic needs of the civil aviation sector, the presidents of the airline companies tried to lay the focus back on the study of possibilities to raise the sector's economic efficiency. The ARB therefore was set up for the duration of one year for the purpose of producing one single report. The main research task was to conduct an analysis of the European air route network and of the methods

40. Instructions for the permanent British delegation at the OEEC, NA, FO 371/99728.

41. Telegram of the British member at the Civil Aviation Committee of AHC to the German Foreign ministry, PA, B 10-794.

42. Report of the British delegation at the OEEC to the FO, NA, FO 371/99728.

43. Note on the meeting of the OEEC's council (16.04.1952), Nationaal Archief Den Haag, Ministerie van Buitenlandse Zaken (MBZ), 2.05.59.02.1501. 
used in order to give practical suggestions for an improvement of the actual situation from a purely European point of view.

The report, which was realized by a study group under the chairmanship of the Belgian professor for transport De Groote, attracted attention all over Europe. It dealt in detail with all aspects of civil aviation. For the ongoing debate on 'air integration' it contained two remarkable results. It (a) judged the internal European market not as an appendix to the intercontinental Air Traffic system, but as a self-supporting market and (b) concluded that "it is better to depend on competition, even when it hurts, than to accept too easily the escape offered by restrictions". 44

\section{Council of Europe}

As mentioned above two committees of the CoE dealt simultaneously with 'air integration': The Bonnefous-Plan was the first on the agenda of the Assembly. It aroused strong opposition by the Scandinavians and the British, who rejected it for its supranational impact, as well as by the majority of European countries, that wanted to separate civil aviation from inland transport. In most countries the ministries of Transport took this view, because civil aviation competed very little with the other modes of transport and furthermore the commercial, technical and administrative problems involved were fundamentally different. ${ }^{45}$ Finally the Bonnefous-Plan was referred to the Committee on Economic Questions for further discussion where it was taken into consideration in the context of the preparation of the Van de Kieft-Plan.

As a second step, the Assembly at its November session of 1951 discussed the Van de Kieft-Plan. This time it were the Dutch and Scandinavian delegates who criticized that a policy of direct market regulation was not explicitly excluded and announced to support only the proposed expert conference. The British delegate questioned the suitability of a long-term objective like the proposed European association, but he supported the convening of an expert conference as a next step. He hoped that this conference might consider the possibility of transferring the matter to the ICAO. The advocates of a politically more significant form of 'air integration', e.g. the Italians, the Belgians and the French, only half-heartedly took part in the discussion. They rather concentrated on the Sforza-Plan and calculated with its getting much more attention within the Committee of ministers than any recommendation by the Assembly. The German delegates according to their policy of wait-and-see did not participate in the debate. ${ }^{46}$ Under the portents of such a constellation of opinions the Van de Kieft-Plan was substantially revised by the

44. Air Research Bureau, Report on Coordination of intra-European Air Transport, Brussels 1953, pp.140-141.

45. Council of Europe, Consultative Assembly, Third Ordinary Session, Official Report of Debates, 05.-15.05.1951, pp.272-283.

46. Report of the German delegation to the Council of Europe to the Foreign ministry, PA, B 10-794. 
delegates from the Netherlands, Scandinavia and Britain: The long term objective, the setting up of one single European association, was to be studied for its suitability and the expert conference was to report on other possible methods to secure the economic and efficient operation of European air transport. In other words, this compromise meant nothing more than a postponement of decision. Therefore it was easily adopted and put on the agenda of the Committee of ministers. ${ }^{47}$

On the background of such a distinct disagreement, further progress within the Committee of ministers seemed illusive. Nevertheless, for the time being, 'air integration' remained on the battlefield of diplomacy. Questions remained unanswered, as for example the aspect of the most suitable political framework for an expert conference or the problem of participation in that conference, as the convening by each organisation, like the CoE, the OEEC or the ICAO, should have excluded particular states. These questions were of importance not only for the Foreign ministries around Europe but also the civil aviation authorities and the airline companies supported a discussion as both preferred to transfer civil aviation to a less political forum than that of the CoE. Especially in Germany, a non-member of ICAO, these questions gave rise to intensive consideration. ${ }^{48}$

Subsequent to its presentation the Committee of ministers referred the Sforza-Plan back to the member governments with request for comments. This procedure caused so much delay that the matter did not reappear on the agenda before December. Then, in order to wait for the outcome of the OEEC's consideration, the Committee of ministers twice postponed the discussion on the Sforza-Plan ${ }^{49}$ and the Assembly's recommendation. ${ }^{50}$ This delay favoured British tactics: After having secured Scandinavian support within UniScan by signalizing the willingness to discuss some measures of liberalisation, the British delegate to the Committee of ministers now was in a position to actively promote the concept of a regional commission under ICAO. ${ }^{51}$

Within the French Foreign ministry the British proposal gave rise to strong opposition. Some actors of the ministry even reacted by drawing up a new plan along the supranational line of the ECSC - a 'blue pool' for civil aviation. Although the French signals for further proceeding did not follow one common line of policy, it was an inner-French consensus that the British proposal was unacceptable, because the United States would thus inevitably play a strong role in any discussion held under the ICAO auspices. Therefore it was agreed that France was to suggest an alternative: i.e. to invite all member states of the $\mathrm{CoE}$ plus

47. Council of Europe, Consultative Assembly, Third Ordinary Session, Recommendation No.12 for the setting up of an association of European airline companies, 07.12.1951.

48. Reports on the meetings of the German ministries, PA, B 10-794.

49. Replies by the Governments of Member States on the Proposal for Co-ordination of Air Transport presented by the Italian Government, Doc. CM (51)79, Archives of the Council of Europe, Strasbourg.

50. Meeting of Ministers' Advisors, Doc. CM/adj (52)19, ACE.

51. Several reports on UniScan meetings, NA, FO 371/99729. 
Austria, Finland, Portugal, Spain, Switzerland and Yugoslavia to an independent conference on 'air integration'. The conference should take into consideration all existing proposals and the results of the Air Research Bureau. ${ }^{52}$ Without defining in detail the conference's objectives or agenda it was intended to be in some way similar to a recent conference on the establishment of a European agricultural pool. $^{53}$

In Foreign ministries all over Europe there was some confusion about the French proposal and its intention. The UniScan countries very soon concluded to reject the invitation as the setting up of a new intergovernmental agency was not excluded. Nevertheless, for Britain a formal rejection was a delicate matter as (a) forestalling the French at that stage by an approach to ICAO could imply the risk that the sincerity of British 'europolitics' was questioned in general and (b) the government did not want to risk further integration between the six ECSC members. For these reasons, the FO was looking for a diplomatic solution with the French before formally rejecting the invitation. In order to check the possibility of a compromise solution the British ambassador at Paris contacted the Foreign ministry's secretary of state, Maurice Schuman, and in detail explained the British position, especially the apprehension of negative consequences for European world-wide services. Schuman stated that he was not informed on any French attempt to organise civil aviation supranationally and that so far the whole issue had been managed by the ministry of Transport. Speaking on behalf of the French government he on the contrary assured that in the context of the highly controversial negotiations about the European Defence Community (EDC), no other ambitious projects of integration would be supported. ${ }^{54}$ Within the FO Schuman's statement was interpreted as a signal of compromise by the French. Obviously they wanted any new European body being closely connected to Britain because this "gives them some guarantee against German domination within the European Community". 55 Schuman, however, signalized that a compromise could not be reached under conditions set exclusively by Britain. He threatened that if Britain

"continued to make difficulties [...] this would encourage the advocates of a 'little Europe' in their belief that attempts to provide for British participation in plans for integrating Europe simply condemned those plans to frustration". ${ }^{56}$

To avoid a formal rejection by the majority of European governments the French adjourned the conference to an unfixed date. Within a ten days period, between the $20^{\text {th }}$ and the $30^{\text {th }}$ of October, an Anglo-French compromise position was concluded between the French and the British secretary-generals for civil aviation, Robert Lemaire and Sir George Cribbet. As both held the opinion that 'air

52. French invitation to British Government, NA, FO 371/99729.

53. G. THIEMEYER, Vom 'Pool Vert' zur Europäischen Wirtschaftsgemeinschaft, Oldenbourg, München 1999.

54. Report of the British ambassador at Paris to the Foreign Office, NA, FO 371/99729.

55. Report of the Foreign Office's delegate de Zulueta, NA, FO 371/99729.

56. Note of the French secretary of State, Maurice Schuman, to the British FO, NA, FO 371/99729. 
integration' was to be kept outside the governmental influence there was a solid basis for a compromise solution. ${ }^{57}$ The compromise was presented to the Council of ministers in November 1952. It suggested that the secretary general of the CoE would invite the ICAO to convene a European conference at the CoE's seat in Strasbourg on three conditions: (a) All countries originally invited to the French conference should be able to participate; (b) The conference's agenda should comprise methods of improving commercial and technical co-operation between airline companies and the possibility of securing closer co-operation in the exchange of commercial rights; (c) A special working party, composed of representatives of those states whose airline companies were participating in the ARB, should be set up to study the problems under consideration by the Bureau. ${ }^{58}$

When presented to the Council of ministers even this proposal was not able to obtain unanimity for several reasons: First, the Netherlands demanded much more attention to be drawn to the study of the ARB as they expected it to plead for liberalisation of the civil aviation sector. The Scandinavians backed this position and expressed their disappointment about the missing reference to the initial OEEC-proposal. ${ }^{59}$ Secondly, they refused their support also for political reasons. After the change at the top of the Foreign ministry from Dirk Stikker to Jan Willem Beyen the attitude towards European integration in general had changed. It became much more focused on continental Europe and did no longer require British participation, at least not at the cost of concessions. Therefore, the Dutch government voted against referring the question to a non-European organisation like ICAO that was believed to open the door to undue influence by non-Europeans. ${ }^{60}$ Thirdly, Germany tried to play for time in order to participate in the proposed conference with full membership capacity after regaining the right for independent civil aviation. Although in principle all German ministries supported the Anglo-French recommendation they proposed to postpone the European air conference until a date, when Germany would be in a position to take effective action on the basis of its own preparatory work. ${ }^{61}$

In the following both the British and the French foreign ministries tried to bring their influence to bear on the highest diplomatic level to get their proposal accepted within the Committee of ministers. The Scandinavian Foreign ministries agreed after being assured of full examination of measures of liberalisation. Especially for Sweden the universal ICAO was in line with the general policy of neutrality.

57. Letter of the French secretary-general for civil aviation, Lemaire, to the secretary-general of the Dutch ministry of Transport, Schaepman, Archief van Ministerie van Buitenlandse Zaken Den Haag, MBZ(45-54)-5-1675.

58. Association of European Air Companies. Draft Resolution presented by the French and United Kingdom delegations, ACE, Doc. CM/12 (52)132.

59. Note on informal contact between the Dutch and the Swedish Foreign ministries, MBZ(45-54)-5-1675.

60. Association of Airline Companies. Proposal of the Representative of the Netherlands, ACE, Doc.CM/12 (52)157.

61. Correspondence of the German Foreign ministry with the ministries of Transport, Economics and Justice, PA, B 10-794. 
Germany simply was not in a position to vote against Britain as future German civil aviation was in need of British support. Finally at the session of March 1953 the Dutch gave in after having been isolated within the Committee of ministers and the Anglo-French compromise was adopted. ${ }^{62}$

\section{ICAO}

The ICAO's council accepted the invitation by the $\mathrm{CoE}$ and appointed a preparatory committee ${ }^{63}$ of national aviation experts to study and recommend general subjects suitable for discussion. ${ }^{64}$ When this committee met in November 1953 to set the agenda, the national points of view had not changed at all. Still the Scandinavians and the Dutch delegates pleaded for some kind of liberalisation whereas especially Britain, France and Italy disliked any kind of liberalisation and preferred a common regulatory approach. The committee's results therefore clearly signalised that neither a multilateral agreement on traffic rights nor the formulation of a common intra-European aviation policy was in reach. Furthermore, a definite decision on the institutionalisation of European civil aviation cooperation seemed unlikely. In particular, the Scandinavians were unwilling to support any permanent arrangement. Maybe the most noticeable aspects of the preparatory committee were the final dropping of the original idea of setting up a single European association and the omission of mentioning a common European air route network. The aviation experts were too strongly focused on their national perspectives to seriously take these points into consideration. Significantly, the conference's agenda was in large parts composed of matters already under discussion within ICAO. The conference to be called was finally named 'Conference on Co-ordination of Air Transport in Europe'; - any link to European integration in general had disappeared. ${ }^{65}$

The 'Conference on Co-ordination of Air Transport in Europe' which was in session between the $21^{\text {st }}$ of April and the $8^{\text {th }}$ of May 1954 was - as it was to be expected - only able to reach limited achievements. Among the delegations present there had not been a sufficient amount of consensus to conclude some kind of multilateral agreement which could have replaced the network of bilateralism: A proposal by the Scandinavians for a multilateral agreement on freedom for scheduled services for a trial period of five years was rejected just as a Dutch proposition on the 'interchange of routes'. The latter should have permitted the airline companies to grant each other the facility to utilize their mutual rights on certain routes. The question of establishing a common European air route network was not even raised. On a multilateral basis only an agreement for non-scheduled

62. Report on the Session of the Committee of ministers, ACE, Doc.CM (53)59.

63. The committee consisted of delegates from Belgium, Denmark, France, Italy, the Netherlands, Norway, Sweden, Switzerland and the United Kingdom.

64. Letter from the secretary-general of the ICAO, Warner, to the CoE's committee of ministers, ACE, Doc.CM (53)59.

65. Reports of the Dutch members within the preparatory committee, MBZ(45-54)-5-1675. 
flights of humanitarian or emergency character could be concluded - an agreement doing no more than codifying the practice already in use. Only some minor adjustments to bilateral agreements were recommended. The participants at least shared the opinion that something had to be done and declared multilateral agreements as desirable objectives. This at least was a necessity to satisfy the Scandinavian and Dutch representatives. Considering the overall results, the head of the Italian delegation regretted that the conference had been "more restricted than Count Sforza had anticipated". ${ }^{6}$

Of major importance for the outcome of the conference was the composition of different actor groups. Within the majority of national delegations the ministries competent for civil aviation had taken over from the Foreign ministries. Due to that change, primarily those delegates negotiated on 'air integration' which previously had failed to conclude a multilateral agreement on operating rights within the ICAO. Many of them were representatives of the national airline companies and regarded their counterparts in other delegations rather as competitors than as partners for cooperation. None of them had in mind to realise a transnational European air route network.

Concerning the organisational aspect of 'air integration', the Dutch delegation on behalf of its Foreign ministry presented a rather vague draft. Without further definition of the assignments the draft simply proposed to set up a permanent conference that would continue the work. The Dutch wanted to take precautions against the founding of any kind of independent organisation with the competence to regulate the intra-European aviation market and hoped to get a long-term forum for discussing measures of liberalisation. ${ }^{67}$ It was calculated that this draft could be accepted as a compromise solution between, on the one hand, the Scandinavians and Britain, which tried to delay a decision on the founding of a new organisation and, on the other hand, Italy, which voted for an authority with full powers to decide on all points under consideration.

On the basis of the draft introduced by Netherlands, the establishment of the 'European Civil Aviation Conference' (ECAC) was finally recommended. This conference should have the objective to (a) continue the work of the recent conference, (b) review the development of intra-European air transport with the objective of promoting coordination, a better utilization and the orderly development of such air transport and (c) consider any special problem that might arise. The ECAC should determine its own internal arrangements but its functions should be consultative. Any conclusion or recommendation should be subject to further approval by the governments. The ECAC should maintain close liaison with the ICAO and should not, at least not from the outset, establish a separate secretariat. ${ }^{68}$ Furthermore, the airline companies were invited to undertake

66. Statement of the Italian chief of delegation, Ambrosini, at the last plenary session, Report on the Conference on Coordination of Air Transport in Europe, Archives of European Civil Aviation Conference, Paris (AECAC), Doc.7575-CATE/1.

67. Instructions for the Dutch delegation to the Strasbourg conference, MBZ(45-54)-5-1675. 
cooperative studies, as being done by the ARB, in order to facilitate the work of the ECAC. ${ }^{69}$ A formal link or even some kind of reference towards the CoE was prevented by the representatives of the civil aviation authorities. They aimed at an organisation of technical character and tried to block any possible political influence by an organisation whose members were regarded as not being competent to decide on civil aviation matters. ${ }^{70}$ This position was backed by the delegations of the non-members of the CoE (Austria, Finland, Portugal, Spain and Switzerland). Apart from that the recommendation did no more than codifying the already existing informal meetings of the airline companies' directors general and was as such accepted by the administrations without resistance. ${ }^{71}$

\section{The European Civil Aviation Conference (ECAC)}

Following the intention that the ECAC would at least have an independent secretariat in Paris, on which the French were able to exert influence, the French ministry of Transport started two further initiatives before the first meeting of the ECAC: ${ }^{72}$ (a) Within the sub-committee for civil aviation of the governmental commission set up by the six ECSC members at the Messina conference, the French delegation tried to convince the other members to agree to a proposal for founding the ECAC on the basis of a protocol that was comparable to the more fixed institutional form of the European Conference for Ministers of Transport (ECMT). ${ }^{73}$ With support of the German and the Italian delegations that proposal was forwarded to the first conference of the ECAC. ${ }^{74}$ (b) Within the ECMT's deputy committee the French tried to get their colleagues to accept an application that the ECMT should extend its competence on civil aviation in order to reach a better coordination between air and inland transport. Even the Belgians urged that the ECMT could not behave indifferently with regard to the ECAC because air and inland transport were in the majority of countries under the competence of the same ministry. As expected, the Dutch, British and Scandinavian delegates refused their support to any kind of proposal and finally no more than a resolution suggesting a harmonious cooperation between ECMT and ECAC was adopted. ${ }^{75}$

68. Recommendation No.28, Report on the Conference on Coordination of Air Transport in Europe, AECAC, Doc.7575-CATE/1.

69. Recommendation No.29, Report on the Conference on Coordination of Air Transport in Europe, AECAC, Doc.7575-CATE/1.

70. Report of the German delegate Ophüls to the Foreign minister, PA, B 10-794.

71. Report of the department L8 of the German ministry of Transport, BArch, Bestand Bundesministerium für Verkehr, B108/6499.

72. Correspondence between the German Foreign ministry and the ministry of Transport, PA, B 13-18.

73. MAE/CIG (22.9.1955), Doc. 269, Archives of the Lufthansa, Cologne.

74. Report of the German delegate Schmidt-Ott on the work done by the sub-committee for civil aviation, BArch, Bestand Bundesministerium für Wirtschaft, B102/22164. 
Under the portent of an aggravated debate on the political aspects of 'air integration', the delegates at the first meeting of the ECAC, which was in session in December 1955, were occupied with the constitution and legal status of the ECAC. Despite all efforts, no progress could be made. The French failed, because it was a common European opinion that France already occupied too many influential positions in secretary offices of international organisations - especially within the transport sector. ${ }^{76}$ In view of the conflicting positions, it finally was decided to adopt a resolution formally constituting the ECAC and to postpone a definite decision on the legal status to an undefined future. By doing so, the ECAC was only given a constitution but no typical legal instrument of an international organisation, like a treaty or convention. The ECAC became closely connected to the ICAO but was neither a regional commission nor incorporated into the ICAO's institutional framework. The juridical basis was simply left open for interpretation. ${ }^{77}$

As in the meantime, passenger traffic within Europe had risen and the airline companies' losses declined, the urgency to increase the economic efficiency of the civil aviation sector had diminished. Therefore, the discussion on a single European association or a common European air route network fell silent and also the report of the ARB recommending measures of liberalisation were ignored by the majority of European Transport ministries.

\section{Conclusion}

In many respects, the ECAC was a compromise solution. Juridically without any definite basis, in its competences restricted to recommendations and without a solid position in the framework of international relations, the ECAC received a rather weak structure. Taking into account the far-reaching objectives of the original proposals for 'air integration' not much of them was left. The ECAC became another organisation to discuss the coordination of administrative or technical matters. It had not the means to take far-reaching economic decisions or to formulate a common European civil aviation policy. Institutionally the ECAC was in no respect connected to other projects of European integration. The reasons for that were manifold: (a) The political and economic objectives of the Western European countries were too divergent; (b) Airline companies were a matter of national prestige and thus called for protection; (c) The ministries of Transport and the airline companies tried to prevent civil aviation from becoming subordinated under economic and political integration in general; (d) 'Air integration' was rather

\footnotetext{
75. Report on the meeting of the deputies committee, BArch, Bestand Bundesministerium für Verkehr, B108/6499.

76. Report of the ministry of Transport's secretary of state, Bergemann, BArch, Bestand Bundesministerium für Verkehr, B108/6153.

77. Report on the first session of ECAC, MBZ(1955-1964)-5-554.221.
} 
unattractive on a smaller geographical scope than the whole of Western Europe; (e) With Germany one of the most active supporters of ambitious projects of integration in general played a negligible role.

The general political and economic integration in Europe turned out to be of overriding importance for 'air integration'. Although the aviation sector had its specific needs and characteristics, 'air integration' was not discussed as a separate project of integration. Especially the British decision to play an active part pushed the discussion closer to other projects of European integration. Each stage of the decision-making process reflected the situation of the overall integration debate at that time. The outcome might have been the totally different if the Scandinavian memorandum within OEEC had not delayed a decision within the CoE until a moment when the negotiations on the EDC had come to a halt.

The existing international organisations contributed to a large extent to raising political awareness for 'air integration' - first and foremost the CoE. While for some countries the OEEC was not an appropriate forum, for others it was the CoE or the ICAO. The more organisations were involved, the smaller did the basis for compromise solutions become. On the other hand, the importance of the existing international organisations should not be downplayed. With their attempts at unifying Europe they triggered off the debate on 'air integration', which beforehand had failed within the ICAO. Often underestimated in its influence on integration processes, the CoE's role was that of a forum of initiative and a push-factor for the decision-making process. In competition with other organisations, it was, however, regarded as being too strongly concentrated on political aspects - especially by technocrats and the sceptics of European integration in general.

Another element influencing the outcome heavily were the specific motivations of the individual actors involved. Visions of a future politically united Europe were the driving force behind the Sforza-Plan and the Bonnefous-Plan. For both, civil aviation more than other sectors lent itself to symbolize a united Europe. Although these visions in some way aroused the discussion on 'air integration', they attracted only some isolated promoters of the European idea and did not have a lasting effect on the discussion on 'air integration'. The decisive motivations instead were the economic calculations of airline companies and the authorities. They supported 'air integration' only when it promised economic advantages - regardless if through liberalisation or regulation. Furthermore, Foreign and Civil aviation ministries regarded airline companies as national symbols. These should operate free from political influence by international organisations. On the administrative level the individual actors were interested in keeping out the Foreign ministers and the ministers of Trade and Economic affairs. For this reason Lemaire and Cribbet were able to agree to the Anglo-French compromise position.

Europe at that time was simply not ready either to build up a transnational European air route network or to create a supranational air authority. Instead it was accepted that each airline company served its own intra-European network even if this was uneconomic. 


\section{Neuauflage!}

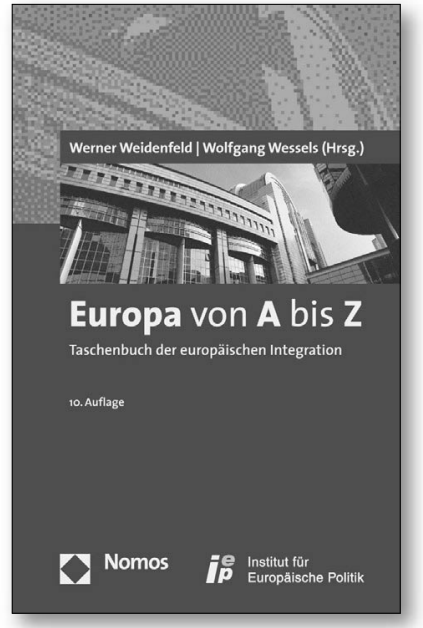

\section{Europa von A bis Z}

Taschenbuch der europäischen Integration

Herausgegeben von

Werner Weidenfeld und

Wolfgang Wessels

10. Auflage 2007, 512 S., brosch., $19,90 €$, ISBN 978-3-8329-2569-7
In Europa überschlagen sich die Ereignisse. Da ist es wichtig, den Überblick zu behalten. Die Neuauflage des Taschenbuches der europäischen Integration hilft dabei durch

- ein umfangreiches Lexikon mit den wichtigsten Themen und Begriffen zu Europa,

- Statistiken und Übersichten zur Bevölkerung, Wirtschaft und Politik,

- eine informative Einführung in die Geschichte der Europäischen Integration,

- eine umfangreiche Linksammlung zu Europa und

- Analysen zur deutschen Präsidentschaft sowie zum Jubiläum „50 Jahre Römische Verträge“.

Renommierte Autorinnen und Autoren aus der Europaforschung erläutern kurz und verständlich die Kernthemen Europas. Das Taschenbuch liefert somit zentrales Hintergrundwissen und ist der perfekte Wegweiser durch das aktuelle Europa: ein unentbehrliches Nachschlagewerk. 